\title{
PERANAN PEMERINTAH DESA DALAM PELAKSANAAN PROGRAM PEMBANGUNAN INFRASTRUKTUR PEDESAAAN (PPIP) DI DESA SENDANA KECAMATAN MAMBI KABUPATEN MAMASA
}

\author{
Indrasto Wahyudi Dahlan ${ }^{1}$, Anwar Parawangi²,Amir Muhiddin ${ }^{1}$ \\ 1Program Studi Ilmu Pemerintahan Fakultas Ilmu Sosial dan Ilmu Politik \\ Universitas Muhammadiyah Makassar \\ Jl. Sultan Alauddin No. 259 Makassar 90221 \\ Telp. 0411-866972 ext.107.Fax.0411-8655888 \\ indrastowd@yahoo.co.id, amirmuh@gmail.com \\ ${ }^{2}$ Program Studi Ilmu Administrasi Negara Fakultas Ilmu Sosial dan Ilmu Politik \\ Universitas Muhammadiyah Makassar \\ Jl. Sultan Alauddin No. 259 Makassar 90221 \\ Telp. 0411-866972 ext.107.Fax.0411-8655888 \\ a.parawangi@gmail.com
}

\begin{abstract}
The study aims to determine the role of village government in Implementing the Rural Infrastructure Development Program (PPIP) In the village Sendana, Mambi district Mamasa Regency. Type research is descriptive qualitative approach is an approach that focuses on the process of data collection in order to describe the state of the object. Data collection technique used by observation, interview and documentation. The result of this study shows that the role of the village government can already be said to play an active role with the following indicator, which is to facilitate the village government to provide facilities at village meetings, implementation of transparency, and support facilities for CSOs. Community engagement where the village government to try and work together with management to prioritize community involvement; supervise and control the implementation of the PPIP. The village government to approach the manager for observing the principles of the PPIP program and use of the budget in accordance with the allocation; fostering CSO where the village government to provide guidance through the values of local wisdom and social capital so that the attitudes and behavior of society for the better organization.
\end{abstract}

Keywords : Village Government, Program, Rural Infrastructure.

\begin{abstract}
ABSTRAK
Penelitian bertujuan untuk mengetahui Peranan Pemerintah Desa Dalam Pelaksanaan Program Pembangunan Infrastruktur Pedesaan (PPIP) Di Desa Sendana Kecamatan Mambi Kabupaten Mamasa Jenis penelitian yang digunakan adalah pendekatan deskriptif kualitatif adalah pendekatan yang menitik beratkan pada proses pengumpulan data. Teknik pengumpulan data menggunakan observasi,wawancara dan dokumentasi. Hasil penelitian ini menunjukkan bahwa peranan Pemerintah Desa sudah dapat dikatakan berperan aktif dengan indikator yaitu: adalah menfasilitasi yang dimana Pemerintah Desa memberikan fasilitas pada musyawarah desa, transpransi pelaksanaan, dan fasilitas penunjang untuk OMS. Keterlibatan masyarakat yang dimana Pemerintah Desa berusaha dan bekerja sama dengan pihak pengelola untuk mengutamakan keterlibatan masyarakat; mengawasi dan mengendalikan pelaksanaan PPIP. Pemerintah Desa melakukan pendekatan kepada pengelola untuk memperhatikan prinsip-prinsip Program PPIP dan penggunaan anggaran sesuai dengan peruntukkannya; membina OMS yang dimana Pemerintah Desa melakukan pembinaan melalui nilainilai kearifan lokal dan modal sosial agar sikap dan perilaku organisasi masyarakat menjadi lebih baik.
\end{abstract}

Kata Kunci : Pemerintah Desa, Program, Infrastruktur Pedesaan. 


\section{A. PENDAHULUAN}

Indonesia memiliki persoalan kemiskinan dan pengangguran. Kemiskinan di Indonesia dapat dilihat dari tiga pendekatan yaitu kemiskinan alamiah, kemiskinan struktural, dan kesenjangan antar wilayah. Lemahnya pembangunan di daerah pedesaan membuat angka kemiskinan dan pengangguran sering dihadapi oleh masyarakat di pedesaan.

Pembangunan nasional diwujudkan dengan melaksanakan mulai dari tingkat desa, daerah sampai tingkat pusat. Pembangunan di sektor pedesaan yang memiliki nilai strategis dalam konteks pembangunan nasional karena $50,21 \%$ penduduk Indonesia bermukim di pedesaan (Sensus penduduk tahun 2010) yang merupakan potensi sumber daya manusia, disamping sumber daya alam yang dimilikinya.

Pembangunan infrastruktur merupakan bentuk dari kepedulian pemerintah, wujud dari model pembangunan tersebut adalah Program Pembangunan Infrastruktur Pedesaan (PPIP). Pemerintah Indonesia melalui Ditjen Cipta Karya, Kementrian Pekerjaan Umum mencanangkan Program Pembangunan Infrastruktur Pedesaan (PPIP) dalam rangka mendukung upaya penanggulangan kemiskinan dan pengembangan infrastruktur permukiman di pedesaan melalui partisipasi masyarakat baik secara individu maupun kelompok sebagai upaya dalam meningkatkan kualitas kehidupan masyarakat.

Provinsi Sulawesi Barat adalah provinsi hasil pemekaran dari Sulawesi Selatan, sejak 05 Oktober 2004 berdasarkan UU.No. 26 Tahun 2004 tentang pembentukan Provinsi Sulawesi Barat. Pemekaran provinsi ini berdampak pada kemandirian Pemerintah Sulawesi Barat dalam mengelola potensi-potensi alam, memberdayakan masyarakat dan urusan pemerintah daerah lainnya. Provinsi Sulawesi Barat sebagai provinsi yang terbilang masih baru penangganan infrastruktur dasar seperti jalan disejumlah kabupaten belum dirasa maksimal terutama di daerah kabupaten Mamasa. Kabupaten Mamasa adalah wilayah di daerah pengunungan yang memiliki akses jalan yang tertinggal dibandingkan kabupaten lainnya diprovinsi Sulawesi Barat. Sebagian besar desadesa di wilayah Kabupaten Mamasa mengalami ketertinggalan dibidang infrastruktur terutama kondisi jalanannya.

Dalam hal ini kebutuhan akan Program Pembangunan Infrastruktur Pedesaan (PPIP), sangatlah dibutuhkan melihat kondisi jalanan di desa tertinggal. Jaringan jalan yang buruk akan menghambat kegiatan masyarakat perdesaan kesentra-sentra ekonomi dan industri disekitarnya, membatasi pemasaran produk yang dihasilkan, atau dapat juga menghambat perjalanan wisatawan jika wilayah tersebut memiliki obyek wisata yang menarik. Lebih dari itu, keterbatasan ketersediaan jaringan jalan yang memadai juga akan mengurangi daya tarik investasi baik yang berasal dari lokal maupunyang dari luar (Arsyad dkk, 2011:10). Peran dari pemerintah kecamatan selaku perangkat daerah kabupaten sebagai pelaksanaan teknis kewilayahan yang dipimpin oleh camat.Camat memiliki peran yang penting dalam penyelenggaraan pembangunan diwilayahnya.

Peran pemerintah desa tidak kalah pentingnya dalam pelaksanaan Program Pembangunan Infrastruktur Pedesaan (PPIP) sesuai Undang-undang Nomor 32 Tahun 2004 tentang Pemerintahan Daerah, "pemerintah desa adalah kepala desa dan perangkat desa sebagai unsur penyelenggara pemerintahan desa". Kebijakan pembangunan yang mengutamakan partisipasi masyarakat di dalam tiap tahapannya memiliki pengaruh besar dalam memberikan ruang kepada masyarakat untuk ikut serta dalam meningkatkan kualitas kehidupannya melalui Program Pembangunan Infrastruktur Pedesaan (PPIP) yang telah diterapkan di Desa Sendana Kecamatan Mambi Kabupaten Mamasa.

Berdasarkan observasi awal yang peneliti lakukan kenyataan bahwa Program Pembangunan Infrastruktur Pedesaan (PPIP) tidak terlaksana secara maskimal seperti tujuan dasar Program Pembangunan Infrastruktur Pedesaan (PPIP) itu sendiri. Terlihat pada pembangunan infrastruktur yang belum terasa manfaatnya bagi sebagian masyarakat desa. Hal ini dikarenakan 
pemerintah desa kurang melakukan mereka relatif homogen serta banyak pengawasan dan pengendalian terhadap bergantung kepada kebaikan-kebaikan pelaksanaan program sehingga terjadi alam.

kebocoran anggaran dan masih kurangnya Berdasarkan beberapa pengertian pemberdayaan terhadap masyarakat. diatas, maka disimpulkan bahwa desa

Pemerintah desa sebagai unit lembaga adalah suatu wilayah yang didalamnya pemerintahan yang paling dekat dengan terdapat sejumlah penduduk yang saling masyarakat diharapkan mampu menjalankan mengenal atas dasar hubungan kekerabatan roda pemerintahan desa dengan sungguh- dan atau kepentingan politik, sosial, sungguh dan mampu merubah taraf hidup ekonomi, dan keamanan yang masyarakat kearah yang lebih sejahtera, adil, pertumbuhannya menjadi kesatuan tentram, aman dan damai.Berdasarkan masyarakat hukum yang bertempat tinggal gambaran di atas, maka penulis tertarik untuk dalam suatu lingkungan dan kehidupannya melakukan penelitian tentang"Peranan relatif homogen serta banyak bergantung Pemerintah Desa dalam Pelaksanaaan Program kepada kebaikan-kebaikan alam.

Pembangunan Infrastruktur Pedesaan (PPIP) di

Desa Sendana Kecamatan Mambi Kabupaten C. PEMERINTAH DESA Mamasa".

Tujuan dari penelitian ini untuk Landasan pemikiran dalam mengenai mengetahui peranan Pemerintah Desa dalam pemerintahan desa adalah Pelaksanaan Program Pembangunan keanekeragamaan, partisipasi, otonomi asli, Infrastruktur Pedesaan (PPIP) di Desa Sendana demokratisasi dan pemberdayaan Kecamatan Mambi Kabupaten Mamasa dan masyarakat.Penyelenggaran pemerintahan untuk mengetahui faktor pendukung dan faktor desa merupakan subsistem dari sistem penghambat peranan Pemerintah Desa dalam penyelenggaraan pemerintahan, sehingga Pelaksanaan Program Pembangunan desa memiliki kewenangan untuk mengatur Infrastruktur Pedesaan (PPIP) di Desa Sendana dan mengurus masyarakatnya sendiri Kecamatan Mambi Kabupaten Mamasa.

\section{B. PENGERTIAN DESA}

(Widjadja, 2003:3).

Pengertian Pemerintahan desa adalah penyelenggaraan urusan pemerintahan dan kepentingan masyarakat setempat dalam

Menurut R.H Unang Soenardjo (dalam sistem pemerintahan Negara Kesatuan Nurcholis, 2011:4) desa adalah sesuatu Republik Indonesia (NKRI).

kesatuan masyarakat berdasarkan adat dan Penyelenggaran pemerintahan desa hukum adat yang menetapkan dalam suatu tidak terpisahkan dari penyelenggaran wilayah yang tertentu batas-batasnya; memiliki otonomi daerah dan pemerintahan desa ikatan lahir dan batin yang sangat kuat, baik merupakan unit terdepan (ujung tombak) karena keturunan maupun karena sama-sama dalam pelayanan kepada masyarakat memiliki kepentingan politik, ekonomi, sosial menjadi tonggak strategis untuk dan keamanan; memiliki susunan pengurus keberhasilan semua program. Karena itu yang dipilih bersama; memiliki kekayaan dalam upaya untuk memperkuat desa merupakan jumlah tertentu dan berhak menyelenggarakan langkah mempercepat terwujudnya urusan rumah tangga sendiri. kesejahteraan masyarakat sebagai tujuan

Menurut Maschab (dalam Wasistiono dan otonomi daerah (Widjaja, 2003:76). Prinsip Tahir, 2007:14) pengertian sosiologis, Desa penyelenggaraan otonomi daerah adalah digambarkan sebagai suatu bentuk kesatuan demokratisasi dan keadilan, masyarakat atau komunitas penduduk yang memperhatikan potensi dan bertempat tinggal dan menetap dalam suatu keanekaragaman daerah, kesesuaian lingkungan, dimana diantara mereka saling hubungan pusat dan daerah, meningkatkan mengenal dengan baik dan corak kehidupan kemandirian daerah dengan meletakkan 
otonomi daerah yang luas dan utuh pada pemerintahan desa. (3) Tertib kepentingan kabupaten atau kota. Kebijaksanaan terbatas umum; Asas yang mendahulukan pada daerah provinsi serta daerah provinsi serta kesejahteraan umum dengan cara aspiratif, desa ditempatkan pada pengakuan otonomi akomodatif, dan selektif. (4) Keterbukaan; asli.Dengan demikian, dalam pengaturan Asas yang membuka diri terhadap hak pemerintah desa telah mengalami pergeseran masyarakat untuk memperoleh informasi paradigma utamanya dalam hal yang benar, jujur dan tidak diskriminatif kewenangan.Pemerintah pusat dan pemerintah tentang penyelenggaraan pemerintahan daerah sebagaimana dimaklumi tidak lagi desa dengan tetap memperhatikan campur tangan secara langsung tetapi ketentuan peraturan perundang-undangan. memberikan pedoman, bimbingan, pelatihan (5) Proporsionalitas; Asas yang atau pembelajaran.Dalam rangka pemberdayaan mengutamakan hak dan kewajiban pemerintah desa, maka diharapkan dapat penyelenggaraan pemerintahan desa. (6) terwujud kondisi pemeritahan desa yang kuat Profesionalitas; Asas yang mengutamakan dan mandiri. (Widjadja, 2003:85).

\section{PERAN PEMERINTAH DESA}

Terjadinya transformasi pemerintahan bahwa setiap kegiatan dan hasil akhir yang dulunya sentralistik menjadi desentralistik kegiatan penyelenggaraan pemerintahan menuntut adanya pemberian wewenang desa harus dapat dipertanggungjawabkan (pendelegasian) bagi penyelenggaraan kepada masyarakat desa sesuai ketentuan pemerintahan Desa. Pemberian otonomi desa ini peraturan perundang-undangan. membutuhkan tata kelola pemerintahan yang Efektivitas dan efisiensi; Efektivitas adalah baik (good governance) sehingga asas yang menentukan bahwa setiap penyelenggaraan pemerintahan di desa dapat kegiatan yang dilaksanakan harus berhasil berjalan dengan baik.

mencapat tujuan yang diinginkan

Good governance menunjukkan bahwa masyarakat desa. Efisiensi adalah asas yang kekuasaan tidak lagi semata-mata dimiliki atau menentukan bahwa setiap kegiatan yang menjadi urusan pemerintah desa, tetapi dilaksanakan harus tetap sesuai dengan menekankan pada pelaksanaan fungsi rencana dan tujuan.(1) Kearifan lokal; Asas pemerintahan secara bersama-sama oleh yang menengaskan bahwa didalam pemerintah desa, masyarakat dan pihak swasta. penetapan kebijakan harus tetap Good governance juga berarti implementasi memperhatikan kebutuhan dan kebijakan sosial-politik untuk kemaslahatan kepentingan masyarakat desa. (2) rakyat banyak, bukan hanya untuk kemakmuran Keberagaman; dan Penyelenggaraan orang perorangan atau kelompok tertentu. pemerintahan desa yang tidak boleh

Penerapan tata kelola pemerintahan yang mendiskriminatif kelompok masyarakat baik di desa mulai terasa dengan pemberian tertentu. (3) Partisipatif. Penyelenggaraan asas-asas pada penyelenggaraan pemerintahan pemerintahan desa yang mengikutsertakan desa yang dilaksanakan oleh pemerintah desa. kelembagaan desa dan unsur masyarakat Peran pemerintah desa dalam penyelenggaraan desa. pemerintahan desa :

(1) Kepastian hukum; Asas dalam negara hukum yang mengutamakan landasan peraturan perundang-undangan, kepatutan, dan keadilan Pembangunan desa adalah suatu dalam setiap kebijakan penyelenggaraan program untuk meningkatkan taraf hidup Pemerintahan Desa. (2) Tertib penyelenggaraan dan kesejahteraan rakyat pedesaan lahir pemerintahan; Asas yang menjadi landasan dan

keteraturan, keserasian, dan keseimbangan

dalam pengendalian penyelenggaraan

PERANAN PEMERINTAH DESA DALAM PELAKSANAAN PROGRAM PEMBANGUNAN INFRASTRUKTUR PEDESAAAN (PPIP) 
batin. Kansil (Patton, 2005:60) mengatakan pemberdayaan adalah sebuah "proses "pembangunan yang dilaksanakan di desa menjadi", bukan sebuah "proses instan". secara menyeluruh dan terpadu dengan Sebagai proses, pemberdayaan mempunyai keseimbangan kewajiban yang serasi antara tiga tahapan yaitu: Tahap pertama pemerintah dan masyarakat, dimana Penyadaran, pada tahap penyadaran ini, target pemerintah wajib memberikan bimbingan, yang hendak diberdayakan diberi pencerahan pengarahan, bantuan dan fasilitas yang dalam bentuk pemberian penyadaran bahwa diperlukan, sedangkan masyarakat mereka mempunyai hak untuk mempunyai memberikan partisipasinya dalam bentuk "sesuatu', prinsip dasarnya adalah membuat swakarsa dan gotong royong pada setiap target mengerti bahwa mereka perlu pembangunan yang diinginkan".

(membangun "demand") diberdayakan, dan

Pembangunan desa adalah upaya proses pemberdayaan itu dimulai dari dalam peningkatan kualitas hidup dan kehidupan diri mereka (bukan dari orang luar).

untuk sebesar-besarnya kesejahteraan Setelah menyadari, tahap kedua adalah masyarakat desa. Dengan demikian dapat Pengkapasitasan, atau memampukan disimpulkan, pembangunan desa bertujuan (enabling) untuk diberi daya atau kuasa, meningkatkan kesejahteraan masyarakat artinya memberikan kapasitas kepada desa dan kualitas hidup manusia serta individu atau kelompok manusia supaya penanggulangan kemiskinan melalui mereka nantinya mampu menerima daya atau penyediaaan pemenuhan kebutuhan dasar, kekuasaan yang akan diberikan. Tahap ketiga pembangunan sarana dan prasarana, adalah Pemberian Daya itu sendiri, pada tahap pengembangan potensi ekonomi lokal, serta ini, kepada target diberikan daya, kekuasaan, pemanfaatan sumber daya alam dan otoritas, atau peluang, namun pemberian ini lingkungan secara berkelanjutan harus sesuai dengan kualitas kecakapan yang menggunakan 2 (dua) pendekatan yaitu desa telah dimiliki mereka.

membangun dan membangun desa yang Pemberdayaan masyarakat sebagai terintegrasikan dalam perencanaan strategi dalam pembangunan masyarakat pembangunan Desa. secara partisipatif.Masyarakat memiliki banya

Pembangunan dilakukan dengan dua potensi, baik dilihat dari sumber-sumber daya pendekatan, yakni pendekataan top down alam yang ada maupun dari segi sumber dan bottom-up. Pendekatan pembangunan sosial-budaya. Masyarakat memiliki top down (dari atas ke bawah) masih "kekuatan" yang bila digali atau disalurkan diperlukan, khususnya untuk program- akan berubah menjadi energi yang besar program pembangunan yang bersifat vital untuk mengatasi masalah yang mereka alami. atau terkait dengan kepentingan orang Cara menggali dan mendayagunakan sumber banyak atau yang merupakan pelayanan daya yang ada dimasyarakat inilah yang antar wilayah, sedangkan pendekatan menjadi inti dari pemberdayaan masyarakat. bottom-up. Perencanaan semacam ini Pemberdayaan masyarakat menjadikan membuat masyarakat langsung yang masyarakat mampu memahami kebutuhan menentukan apa yang direncanakan, dengan dan permasalahan yang dihadapi. Mereka juga cara apa akan dilakukan dan yang paling dilatih untuk dapat merumuskan rencanamenjadi dasarnya adalah perencanaan akan rencananya serta melaksanakan sesuai dengan kebutuhan masyarakat desa pembangunan secara mandiri dan swadaya. itu sendiri sehingga kegunaan dari Dengan perkataaan lain, gerakan pembangunan yang akan dilaksanakan akan pemberdayaan dalam pembangunan "dari, sangat berarti dan berguna bagi kebutuhan oleh dan untuk" masyarakat (Harry Hikmat, masyarakat desa tersebut.

\section{F. PEMBERDAYAAN MASYARAKAT DESA} 2010:217-218)

Pemberdayaan Masyarakat Desa adalah upaya

Menurut Ketaren dalam Ananda (2013)

PERANAN PEMERINTAH DESA DALAM PELAKSANAAN PROGRAM PEMBANGUNAN INFRASTRUKTUR PEDESAAAN (PPIP) 
mengembangkan kemandirian dan kesejahteraan pemilihan dilakukan berdasarkan musyawarah masyarakat dengan meningkatkan pengetahuan, desa sehingga dapat diterima oleh masyarakat sikap, keterampilan, perilaku, kemampuan, kesadaran, secara (acceptable). Prinsip ini berlaku dari sejak serta memanfaatkan sumber daya melalui penetapan pemilihan lokasi pembangunan infrastruktur, kebijakan, program, kegiatan, dan pendampinganyang penentuan mekanisme pengadaan dan sesuai dengan esensi masalah dan prioritas kebutuhan pelaksanaan kegiatan, termasuk pada penetapan masyarakat desa.

Pemberdayaan masyarakat desa bertujuan (2) Transparansi, penyelenggaraan kegiatan meningkatkan kemampuan dan kemandirian masyarakat secara terbuka dan diketahui oleh masyarakat dalam meningkatkan taraf semua unsur masyarakat (transparent). hidupnya.Pemberdayaan masyarakatpedesaan dalam Tranparansi antara lain dilakukan melalui hal pembangunan memberikan ruang kepada penyebaran informasi pelaksanaan dan program masyarakat untuk turut aktif (berpartisipasi) dalam secara akurat dan mudah diakses oleh tiap tahapan pembangunan.Pembangunan masyarakat. (3) Akuntabel, penyelenggaran partisipastif diharapkan sesuai dengan kebutuhan atau kegiatan yang dilaksanakan masyarakat harus masalahyang dihadapi masyarakat desa.

\section{G. PROGRAM PEMBANGUNAN INFRASTRUKTUR PEDESAAN (PPIP)} dapat dipertanggung (accountable), dalam hal ketepatan sasasran, waktu, pembiayaan, dan Program Pembangunan Infrastruktur masyarakat secara berkelanjutan (sustainable) Pedesaan (PPIP) merupakan program yang ditandai dengan adanya rencana berbasis pemberdayaan masyarakat dibawah pemanfaatan, pemiliharaan dan pengelolaan payung Program Nasional Pemberdayaan terbangun secara mandiri oleh masyarakat.

Masyarakat Mandiri (PNPM Mandiri), yang komponen kegiatannya meliputi fasilitas dan mobilisasi masyarakat sehingga mampu melakukan identifikasi permasalahan ketersediaan dan akses keinfrastruktur dasar, menyusun perencanaan dan melaksanakan pembangunan infrastruktur dasar.

Program Pembangunan Infrastruktur Pedesaan (PPIP) hadir dengan maksud dan tujuan : (1) Maksud : Sebagai upaya mendukung percepatan penanggulangan kemiskinan dan memperkuat implementasi tata kelola pemerintahan yang baik (good governance). (2) Tujuan : Untuk mewujudkan peningkatan akses masyarakat, miskin dan kaum perempuan, termasuk kaum minoritas kepelayanan infrastruktur dasar permukiman perdesaan, yang mendukung pengembangan potensi desa dengan berbasis pada pendekatan pemberdayaan masyarakat dan peningkatan tata kelola pemerintahan yang baik.

\section{H. PERANAN PEMERINTAH DESA DALAM PELAKSANAAN PROGRAM PEMBANGUNAN INFRASTRUKTUR PEDESAAN (PPIP)}

Definisi peranan menurut Departemen Pendidikan Nasional (2002:854) dalam Kamus Besar Bahasa Indonesia Edisi ketiga memberikan arti peranan, "tindakan yang dilakukan oleh seseorang dalam suatu peristiwa". sedangkan menurut Pariata Westa dalam Tuti (2003:9) mengatakan peranan dapat diartikan sebagai terlaksananya suatu fungsi atau tugas tentang sesuatu hal untuk mencapai tujuan yang telah ditentukan. Dapat disimpulkan peranan merupakan segala sesuatu tindakan yang dilakukan dengan sengaja yang bertujuan untuk mencapai suatu hal yang telah ditentukan.

Peranan Pemerintah desa yang diatur dalam pedoman pelaksanaan PPIP, diantaranya : Mengkoordinasikan penyelenggaraan PPIP diwilayah kerjanya; Program Pembangunan Infrastruktur Menyelenggarakan Musyawarah Desa Pedesaan (PPIP) menekankan prinsip-prinsip Persiapan (sosialisasi dan pembentukan OMS, diantaranya: (1) Dapat diterima (acceptable), KPP dan KD) dan memfasilitasi musyawarah 
desa selanjutnya; Menjamin dan Pemerintah Desa dalam pelaksanaan Program memfasilitasi keterlibatan Pembangunan Infrastruktur Pedesaan (PPIP). perempuan/minoritas dan orang miskin Teknik pengumpulan data diantaranya dalam setiap tahapan kegiatan; Memantau observasi, wawancara, dan dokumentasi. penerapan prinsip-prinsip PPIP dalam deskriptif kualitatif, dengan model analisis pelaksanaan tiap tahapan kegiatan; interaktif.

Memfasilitasi terbentuknya OMS, KPP dan KD yang dilakukan melalui forum musyawarah J. HASIL DAN PEMBAHASAN

tingkat desa; Membantu kelancaran proses Memfasilitasi berasal dari kata fasilitas penyusunan Rencana Kerja Masyarakat; yang secara harfiah merujuk pada "upaya Mengetahui dan menyetujui hasil memberikan kemudahan" kepada siapa saja perencanaan dan hasil pelaksanaan kegiatan; agar mampu mengerahkan potensi dan Melaksanakan pengendalian pelaksanaan sumber daya untuk memecahkan masalah kegiatan; Menjamin dan memfasilitasi yang dihadapinya (Wahyudin Sumpeno, trasnparansi pelaksaan kegiatan; 2009:2). Pemberian fasilitas pada Menyiapkan Posko OMS yang digunakan penyelenggaraan PPIP akan menunjang sebagai sekertaris program desa; Turut kelancaran pelaksanaannya. Pemberian menandatangani surat pernyataan fasilitas ini tidak hanya dilakukan oleh pihak penyelesaian kegiatan (SP2K) yang dibuat pengelola tetapi pihak pemerintah setempat oleh ketua OMS; Memfasilitasi KPP untuk turut memberikan bantuan sehingga dapat melakukan pengawasan pelaksanaan menyukseskan proses pembangunan kegiatan dan pengelolaan hasil infrastruktur infrastruktur.

terbangun; Menerima infrastruktur Fasilitas yang diberikan oleh pemerintah terbangun dari Pemerintah Kabupaten dan desa di antaranya pada saat pelaksanaan meneruskan pengelolaannya kepada musywarah desa.

masyarakat melalui KPP; Mendukung "Muswayarah desa sangat menentukan pelaksanaan PPIP melalui sinkronisasi program dan channeling ke stakeholder lainnya; Membina OMS agar berfungsi secara berkelanjutan dalam proses perencanaan pembangunan partisipastif selanjutnya; Menandatangani serta mentaati Pakta Integritas bersama wakil rakyat.

\section{METODE PENELITIAN}

Jenis penelitian ini adalah jenis penelitian kualitatif. Suharsimi Arikunto (2005:234) berpendapat bahwa dalam Bapak Kepala Desa Sendana menunjukkan penelitian kualitatif menitik beratkan pada bahwa kepedulian Pemerintah Desa sendana proses pengumpulan data supaya dapat dalam pelaksanaan musyawarah desa sebagai menggambarkan keadaan obyek penelitian salah satu proses awal dan terpenting dalam apa adanya berdasarkan fakta-fakta yang penyelenggaraan dan pelaksanaan program tampak sebagaimana adanya.

PPIP. Musyawarah desa yang ditunjang sarana

Tipe penelitian ini menggunakan dan prasarana yang memadai akan pendekatan deskriptif yang berkaitan dengan menciptakan rasa nyaman dan mendorong objek penelitian tentang bagaimana membuat, partisipasi masyarakat dan pihak-pihak yang menggambarkan, meringkas berbagai kondisi terlibat dalam penyelenggaraan dan dan situasi yang timbul di lapangan.Dengan pelaksanaan program PPIP untuk lebih fokus menetapkan fokus pada masalah peranan mengikuti agenda musyawarah desa 
Pemberian fasilitas dalam penyelenggaraan yang matang agar didalam diri masyarakat PPIP sangat membantu pengelola sesuai hasil tumbuh rasa memiliki dan rasa tanggung wawancara dengan ketua OMS bahwa : jawab terhadap hasil pembangunan yang telah

"Saya sangat berterima kasih kepada terlaksana didesanya. Besar kecilnya Bapak kepala desa karena perannya partisipasi masyarakat merupakan faktor dalam memberikan fasilitas kepada penting dalam proses pembangunan. kami sehingga tugas-tugas yang Pembangunan desa sangat memerlukan diemban oleh OMS dan KPP dapat adanya keterlibatan aktif dilaksanakan sebagaimana masyarakat.Keikutsertaan masyarakat tidak mestinya.Bapak kepala desa saja dalam perencanaan tetapi juga meminjamkan 1 (satu) buah leptop pelaksanaan program-program pembangunan untuk dipergunakan mengelola di desa.Berikut disajikan wawancara dengan administrasi, diberikan alat tulis infromanperangkat desa, kaur pembangunan: menulis, memberikan 1 (satu) buah ruangan di kantornya untuk di jadikan posko OMS sekaligus digunakan sebagai sekertariat program di desa. (wawancara, $H S$ )

Dari wawancara dengan ketua OMS Desa Sendana dapat disimpulkan bahwa pemerintah desa berperan dalam memberikan fasilitas untuk pemberdayaan OMS dan KPP yang ada didesanya. Fasilitas "Sasaran pelaksanaan PPIP di Desa adalah masyarakat miskin dan kelembagaan sebagai pengelola.Maka sudah tentu masyarakatlah yang terlibat langsung.Pemerintah Desa selalu memantau pelaksanaan tahapan PPIP sekaligus mendorong pengelola untuk sepenuhnya melibatkan masyarakat kurang mampu dalam pelaksanaannya. (Wawancara, RN).

Dari wawancara dengan perangkat desa yang diberikan sangat membantu kinerja sendana dapat disimpulkan bahwa keterlibatan OMS dalam mengerjakan administrasi masyarakat dalam setiap pelaksanaan pembangunan pengelolaan PPIP seperti laporan menjadi dorongan utama yang dilakukan Pemerintah pelaksanaan kegiatan, laporan keuangan, Desa. Sesuai kondisi yang ditemukan peneliti di laporan penggunaan dana yang dilaksanakan lapangan memang dengan melibatkan masyarakat secara berkala satu minggu sekali, dapat dalam pelaksanaan pembangunan memberikan dilaksanakan secara berkesinambungan dan dampak positif terhadap keberlangsungan hidup hampir tidak ada yang terlewatkan.

masyarakat Desa Sendana. Fakta lain yang bisa terlihat b. Peranan Pemerintah Desa dalam adalah tingginya peran partisipatif masyarakat akan Menjamin Keterlibatan Masyarakat kesadaran dalam menjaga dan memelihara

Tujuan utama dari pembangunan yang lingkungannya.

dilaksanakan pemerintah adalah untuk Selain itu masyarakat dalam kategori miskin di meningkatkan taraf hidup masyarakat desa. Desa Sendana sedikit demi sedikit bisa Masyarakat sebagai aktor dan pelaku memperlihatkan perubahan yang signifikan dalam pembangunan diharapkan benar-benar meningkatkan taraf hidupnya.

mengerti akan tujuan, sasaran, prinsipprinsip serta nilai-nilai akan pembangunan1. yang dilaksanakan didesa. Masyarakat desa sebagai sasaran pembangunan ditingkat desa diharapkan dapat mengetahui hak dan

\section{Peranan Pemerintah Desa dalam Mengawasi dan Mengendalikan Pelaksanaan PPIP}

Menurut Dale (Winardi, 2000:224) kewajibannya dalam pengelolaan pengawasan tidak hanya melihat sesuatu pembangunan yang dilaksanakan oleh dengan seksama dan melaporkan hasil pemerintah di desanya.

Keterlibatan masyarakat dalam

pembangunan perlu dilakukan persiapan 
arti memperbaiki dan meluruskannya diketahui bahwa Pemerintah Desa sehingga mencapai tujuan yang sesuai memberikan penegasan kepada pihak dengan apa yang direncanakan. Hal ini pengelola agar melaksanakan pembangunan berarti pengawasan tidak hanya dilakukan sesuai prinsip-prinsip PPIP.Komunikasi untuk mengamati tetapi melaksanakan senantiasa dilakukan Pemerintah Desa dalam pengendalian sehingga tujuan sebelumnya mengawasi dan mengendalikan pelaksanaan dapat tercapai.

Pemerintah Desa bertanggung jawab pembangunan.

terhadap kelancaran pembangunan dalam Meningkatnya mutu pembangunan tidak wilayahnya.Membangun desa merupakan hanya dengan penerapan prinsip-prinsip PPIP upaya peningkatan kualitas hidup dan tetapi pemerintah desa turut serta dalam kehidupan untuk sebesar-besarnya mengawasi dan mengendalikan pengelolaan kesejahteraan masyarakat desa.Peranan anggaran pembangunan.Berikut ini pemerintah desa dalam mengawasi dan wawancara dengan ketua OMS memberikan mengendalikan pelaksanaan PPIP di desa stekmennya sebagai berikut:

sangat di butuhkan untuk memperkuat tugas

"Pemerintah Desa

melakukan

dan fungsi setiap unsur dalam pelaksanaan PPIP di Desa Sendana Kecamatan Mambi Kabupaten Mamasa.

Tugas dan fungsi setiap unsur dimaksud di atas adalah terbatas pada Pemerintah Desa, masyarakat yang tergabung dalam lembaga OMS, KPP dan KD.Kedua unsur ini, juga merupakan penentu apakah pelaksanaan PPIP di desa dapat berjalan secara efektif, efesien dan berkelanjutan atau tidak. Mengetahui bagaimana peran disampaikan oleh HL selaku ketua OMS dapat
Pemerintah Desa dalam mengawasi dan disimpulkan bahwa Pemerintah Desa dalam pengawasan dan pengendalian dalam pelaksanaan PPIP dalam hal mutu, biaya, dan waktu yang ditentukan, termasuk mengecek di lapangan apakah masyarakat berpartisipasi dalam tahapan pelaksanaannya atau tidak.Kepala desa juga sangat ingin memastikan apakah masyarakat miskin dilibatkan atau tidak. (wawancara, $H L$ )

Berdasarkan hasil wawancara yang mengendalikan pelaksanaan PPIP di desa hal ini Bapak Kepala Desa Sendana melakukan sendana, maka peneliti mengambil 2 (dua) fungsinya secara maksimal dalam mengawasi alternatif sebagai tolak ukur yakni "untuk dan mengendalikan pelaksanaan program mengetahui penerapan prinsip-prinsip PPIP PPIP di desanya.Penggunaan biayapun sangat dalam pelaksanaan tiap tahapan kegiatan dan diharapkan untuk dilakukan secara pengelolaan anggaran pembangunan". Untuk tranparansi sesuai dengan peruntukannya lebih jelasnya dapat dilihat dari wawancara sehingga dapat bermanfaat bagi masyarakat dengan sekertaris desa dibawah ini: banyak.Tingkat partisipasi masyarakat, "Pemerintah desa dalam hal ini Bapak keterlibatan masyarakat miskin, langsung di Kepala Desa cukup berperan dalam cek dilapangan.

$\begin{array}{lllr}\text { mengawasi dan mengendalikan 2. } & \text { Peranan Pemerintah Desa dalam } \\ \text { pelaksanaan PPIP di desa ini, Kepala } & \text { Membina Organisasi } & \text { Masyarakat } \\ \text { Desa memiliki kinerja yang cukup baik } & \text { Setempat (OMS) }\end{array}$
dalam melakukan koordinasi. Kepala

Pembinaan berasal dari kata "bina" yang Desa melakukan penegasan kepada berati sama dengan "bangun". Jadi pembinaan pengelola PPIP di desa ini untuk dapat diartikan sebagai kegunaan yaitu: melaksanakan sesuai dengan prinsip- merubah sesuatu sehingga menjadi baru yang prinsip PPIP dalam setiap tahapan memiliki nilai-nilai yang tinggi. Dengan kegiatan. (wawancara, IS).

demikian pembinaan dapat juga diartikan Dari hasil wawancara diatas dapat sebagai pembaharuan, yaitu: melakukan 
usaha-usaha untuk membuat sesuatu

Dari hasil wawancara diatas dapat menjadi lebih sesuai atau cocok dengan disimpulkan bahwa pemerintah desa sendana kebutuhan dan menjadi lebih baik dan ternyata mempunyai persiapan yang cukup bermanfaat (Pamudji, S 1985:7). Sedangkan matang dalam mempersiapkan OMSnya menurut Soetopo, H dan Soemanto, W sebelum melaksanakan fungsi-fungsinya 1991:43) bahwa pembinaan adalah sesuatu dalam mengelola PPIP yang masuk di desanya. kegiatan mempertahankan dan Dengan gaya kepemimpinan yang dimilikinya menyempurnakan apa yang telah ada. Dapat mampu melobi ke tingkat kabupaten untuk disimpulkan bahwa pembinaan adalah usaha bekerja sama membina OMSnya agar dapat atau tindakan yang dilakukan dalam rangka bekerja secara efektif, efisien dan tepat waktu membuat sesuatu menjadi lebih sesuai agar sesuai yang telah ditentukan.

mampu mempertahankan dan Pembinaan Organisasi Masyarakat menyempurnakan apa yang telah ada.

Setempat (OMS) memiliki cakupan yang cukup

Salah satu tugas Pemerintah Desa banyak, akan tetapi yang jelas pembinaan dalam penyelenggaraan pembangunan mengandung arti memberdayakan adalah membina organisasi masyarakat yang masyarakat agar dalam melakukan sesuatu ada di desanya agar dapat berfungsi secara program menghasilkan nilai tinggi dan berkelanjutan dalam proses perencanaan mengandung makna sebagai pembaharuan. pembangunan partisipatif. Kewenangan Pembinaan masyarakat yang berorientasi Pemerintah Desa dalam membina kehidupan pada pemberdayaan masyarakat merupakan masyarakat, merupakan salah satu unsur usaha untuk membuat sesuatu menjadi sesuai yang sangat penting dalam proses dengan kebutuhan, menjadi lebih baik dan pembangunan sekaligus pemberdayaan lebih bermanfaat bagi masyarakat. masyarakat. Tujuannya adalah agar 3. Faktor Pendukung dan Penghambat masyarakat yang tergabung dalam organisasi Berdasarkan hasil observasi dan masyarakat mengetahui dan mengerti apa wawancara yang peneliti lakukan, dapat yang harus dikerjakan serta dapat diketahui faktor pendukung dan penghambat menimbulkan kesadarannya untuk ikut aktif pemerintah desa dalam pelaksanaan program dalam setiap pelaksanaan dan pengelolaan pembangunan infrastruktur pedesaan:

pembangunan.

1. Faktor Pendukung

Didalam

pedoman

tersebut

Sumber daya manusia (masyarakat) memposisikan OMS sebagai aktor utama merupakan unsur yang sangat penting dalam pelaksana kegiatan PPIP di tingkat desa, pelaksanaan program PPIP, karena sehingga mau tak mau Pemerintah Desa masyarakat sebagai pelaksana sekaligus melakukan pendampingan berupa sebagai sasaran infrastruktur yang akan pembinaan. Di bawah ini hasil wawancara dibangun di desanya, pemerintah hanya dengan Bapak Kepala Desa Sendana memfasilitasi agar dapat terlaksana sesuai memberikan penjelasan sebagai berikut: petunjuk teknik operasional yang telah "OMS merupakan pelaku utama dalam ditentukan.

pengelolaan PPIP.Jadi harus Dukungan masyarakat akan dipersiapkan secara matang agar benar- pembangunan di desanya menjadi faktor benar dapat melaksanakan fungsinya utama sehingga pembangunan dapat dalam kegiatan PPIP. Pemerintah desa terlaksana sesuai keinginan masyarakat desa. bekerja sama dengan Satuan Kerja Berikut hasil wawancara dengan Ismal selaku tingkat Kabupaten dalam hal ini Pejabat Sekertaris Desa Sendana :

Pembuat Komitmen Pembangunan

Infrastruktur Pedesaan untuk

melakukan pembinaan OMS.

(wawancara,MN)

"Faktor dari keberhasilan setiap program yang masuk ke desa karena adanya dukungan dari masyarakat, baik program dalam bentuk fisik maupun non fisik,

PERANAN PEMERINTAH DESA DALAM PELAKSANAAN PROGRAM PEMBANGUNAN INFRASTRUKTUR PEDESAAAN (PPIP) 
dalam pelaksanaan PPIP sendiri masyarakat pengawasan, dan pelaporan program. menyadari akan pentingnya keikutsertaan 3. Fasilitator masyarakat

mereka baik pada saat perencanaan, Fasilitator masyarakat adalah pelaksanaan, sampai pemiliharaan." pendamping masyarakat secara langsung (wawancara, IS) dalam melaksanakan program PPIP di desa sasaran.Fasilitator Masyarakat bertugas

Berdasarkan wawancara di atas memberikan motivasi, bimbingan dan dukungan dari masyarakat dalam pembinaan OMS, KPP, dan KD. Fasilitator pelaksanaan program PPIP sangat penting pemberdayaan dan fasilitator teknik dan mendukung dalam efektifitas pencapaian mempunyai tugas dalam pelaksanaan hasil yang diinginkan. Pengaruh masyarakat program PPIP adalah membantu dan dalam pelaksanaan program PPIP yang mendampingi masyarakat untuk berbasis pemberdayaan masyarakat ini melaksanakan seluruh proses dan prosedur sangat banyak, karena dalam pelaksanaan yang tertuang dalam pedoman pelaksanaan program pembangunan fisik seperti program PPIP, memberikan pemahaman pembangunan infrastruktur rabat beton, terkait dengan petunjuk teknik infrastruktur, talud, drainase dan MCK di Desa Sendana penyusunan Rencana Anggara Biaya (RAB) merupakan hasil kerja masyarakat untuk dan Rencana Kerja Masyarakat (RKM).

turun langsung mengerjakan, pemerintah Berikut hasil wawancara dengan salah hanya memfasilitasi dan mengendalikan satu perangkat Desa Sendana: bagaimana bisa terlaksana dengan baik.

Faktor dana juga tidak kalah penting dalam mendukung pelaksanaan program PPIP, karena masyarakat tidak akan dapat mengerjakan suatu kegiatan tanpa didukung ketersediaan dana. Berikut hasil wawacara dengan kepala desa sendana :

"Faktor yang memudahkan tugas kami dalam menfasilitasi dikarenakan adanya bantuan berupa dana operasional bagi OMS untuk memenuhi setiap kebutuhan mereka dalam menjalankan tugasnya sebab anggaran dana desa terbatas. Dana operasional sangatlah membantu pemerintah desa dalam mengefisienkan anggaran dana desa untuk kebutuhan masyarakat maupun aparatur pemerintah desa dalam menjalankan tugas-tugasnya" (wawancara, MN)

Dari wawancara di atas peneliti dapat mengutip bahwa dana operasional dipergunakan untuk pemenuhan kebutuhan OMS dalam menjalankan setiap tugasnya. Dana ini tidak boleh disalah gunakan untuk kepentingan pribadi maupun kelompok.Tujuan dari pendanaan ini sendiri demi kelancaran pekerjaan OMS pada tahap persiapan, perencanaan, pelaksanaan,
"Fasilitator Masyarakat adalah salah satu faktor yang memudahkan tugas kami, diantaranya membantu mengadakan musyawarah desa, mengajak masyarakat untuk ikut berpartisipasi dalam setiap tahap kegiatan program bahkan melakukan pembinaan terhadap OMS, $K P P$ dan KD. Saya sangat bersyukur karena berkat adanya fasilitator masyarakat semua tugas tidak kami lakukan sendiri tapi bersama-sama sehingga tiap tahapan kegiatan dapat berjalan dengan baik" (wawancara, RN)

Senada dengan wawancara di atas salah satu masyarakat berpendapat:

"Dengan adanya fasilitator masyarakat sangatlah membantu dalam pelaksanaan rancangan program PPIP, karena fasilitator masyarakatlah yang menyiapkan segala fasilitas dan kebutuhan masyarakat dalam mengoptimalkan program PPIP di desa sendana. Saya melihat tugas fasilitator sangat berat, tanpa adanya fasilitator masyarakat maka secara otomatis program PPIP di desa ini tidak dapat terlaksana secara maksimal." (wawancara, MD) 
Berdasarkan wawancara di atas peniliti kepala Desa Sendana peneliti dapat mengutip dapat mengutip bahwa fasilitator masyarakat bahwa tingkat pendidikan masyarakat yang memiliki pengaruh dalam proses rendah dapat mengakibatkan tidak pelaksanaan program PPIP. Tenaga fasilitator maksimalnya peranan pemerintah desa dalam tidak hanya membantu pihak pemerintah pelaksanaan tahapan-tahapan program desa dalam menyediakan fasilitas dalam pembangunan infrastruktur pedesaan (PPIP) penyelenggaraan PPIP tapi juga membantu yang dilaksanakan di desanya. Senada dengan mengarahkan masyarakat dalam membuat pendapat di atas, Tokoh masyarakat atau merancang RAB dan RKM yang berpendapat: merupakan bagian awal dari pembangunan. Perencanaan yang matang akan berdampak pada penggunaan anggaran yang lebih efisien danpada akhirnya program pembangunan dapat dilakukan secara maksimal.

b. Faktor Penghambat

Tingkat pendidikan memiliki kaitan dengan tingkat kemampuan masyarakat dalam melaksanakan sebuah program pembangunan. Hal ini didasarkan pada asumsi bahwa masyarakat yang memiliki pendidikan tinggi akan mampu memahami dan menjawab persoalan tugas dan pekerjaan yang dihadapi sehingga dapat meningkatkan kinerja mereka. Sebaliknya masyarakat yang memiliki tingkat tokoh masyarakat dapat di simpulkan bahwa pendidikan yang rendah akan kurang mampu tingkat pendidikan masyarakat desa sendana memahami dan menjawab persoalan tugas menjadi sebuah kendala sekaligus tantangan dan tanggung jawabnya dalam sebuah bagi pemerintah desa maupun penyelenggara pekerjaan.

Berikut akan dipaparkan tanggapan informan benar tidaknya tingkat pendidikan masyarakat masyarakat merupakan faktor penghambat pembinaan maupun pengarahan dilakukan peranan pemerintah desa dalam pelaksanaan berkali-kali sehingga masyarakat akan lebih Program Pembanguan Infrastruktur baik dalam melaksanakan peran mereka di Pedesaan (PPIP) di desa sendana.

"Masyarakat desa sendana 60,3 persen dalam program ini.

Faktor sarana dan prasarana kerja juga bermata pencaharian sebagai petani menjadi penghambat peranan pemerintah dan peternak dan rata-rata hanya tamat desa dalam pelaksanaan Program sekolah dasar, bahkan ada yang sama Pembangunan Infrastruktur Pedesaan (PPIP) sekali tidak pernah duduk di bangku di Desa Sendana. Pada hal sarana dan sekolah. Kondisi inilah salah satunya prasarana mestinya merupakan hal penting yang menghambat peranan pemerintah dalam proses pelaksanaan dan desa dalam melaksanakan tahapan- penyelenggaraan sebuah aktifitas. Sarana dan tahapan PPIP, mulai dari tahap prsarana adalah setiap benda atau alat yang penyiapan, sosialisasi, perencanaan, dipergunakan untuk memperlancar atau pelaksanaan dan pemeliharaan" mempermudah sebuah pekerjaan.

(wawancara, $M N$ )

Peralatan yang dimiliki di samping harus cukup secara kuantitas, juga harus baik dan Dari wawancara diatas dengan bapak tepat untuk satu tujuan.Semakin baik 
peralatan yang dimiliki, semakin memperlancar dan mempermudah mekanisme kerja dan mempercepat penyelesaian kerja. Menurut Nawawi 1984 (dalam Muthar 2013:91) bahwa alat pada dasarnya merupakan sumber kerja material hanya patut dipergunakan apabila mampu meningkatkan hasil yang dicapai m dibandingkan dengan cara kerja tanpa mempergunakan alat.

$\begin{array}{lcc}\text { mengangkut } & \text { material } & \begin{array}{l}\text { dengan } \\ \text { mengunakan }\end{array} \\ \text { (wawancara, SS). } & & \text { gabah". }\end{array}$

Faktor sarana dan prasarana menurut pada waktunya. Apalagi kalau Pemerintah beberapa informan di Desa Sendana atau Desa tidak melakukan perannya secara masyarakat yang terjun langsung sebagai totalitas.

tenaga kerja pada pelaksanaan Program Pembangunaan Infrastruktur Pedesaan K. PENUTUP

(PPIP), mempersoalkan ketersedian sarana Berdasarkan dari hasil penelitian dan dan prasarana yang mengakibatkan pembahasan, maka dapat disimpulkan bahwa pelaksanaan PPIP tidak selesai tepat pada pemerintah desa sendana sudah menjalankan waktunya. Masyarakat sangat menyoroti tugasnya dengan baik dengan hasil Pemerintah Desa Sendana dan Organisasi pembangunan yang sudah dirasakan oleh Masyarakat Setempat. masyarakat desa tersebut atau masyarakat Berikut hasil wawancara dengan desa lain yang kebetulan lewat untuk lebih masyarakat Desa Sendana, pada saat peneliti jelasnya dapat diuraikan sebagai berikut:

mengambil gambar hasil pembangunan fisik (1) Peranan Pemerintah Desa dalam yang di Danai oleh Progam Pembangunaan menfasilitasi penyelenggaraan Program Infrastruktur Pedesaan (PPIP).

Pembangunan Infrastruktur Pedesaan (PPIP)

"Pengerjaan rabat beton ini kami tidak di Desa Sendana dapat dikatakan cukup baik. bisa selesaikan tepat pada waktunya, Dibuktikan dengan fasilititas yang diberikan karena pendistribusian material selalu saat pelaksanaan muswayarah desa, terlampat dilokasi akibat sarana dan tranparansi pelaksanaan maupun fasilitas prasarana kurang memadai.Kualitas untuk OMS dan KPP yang memberikan bangunannya juga berbeda dengan yang manfaat tersendiri bagi masyarakat dan awal-awal, karena kami dikejar-kejar pengelola PPIP. (2) Peranan Pemerintah Desa oleh waktu. Kami kuatir bangunan rabat dalam menjamin keterlibatan masyarakat beton ini tidak akan bertahan lama, dan dalam tahapan-tahapan pelaksanaan PPIP di sangat merugikan masyarakat. Desa Sendana sudah tergolong baik, dengan (wawancara, $A R$ ) pelibatan masyarakat pembangunan dapat sesuai kebutuhan masyarakat desa dan

Begitu pula diungkapkan oleh seorang masyarakat desa dapat berpikir dalam petani berikut ini: pengambilan sebuah keputusan menyangkut "Pada saat awal-awal diakui Pemerintah hak dan kewajiban dalam pengelolaan, Desa sangat memperhatikan hal-hal pelaksanaan dan pemanfaatan serta yang bisa menghambat kelancaran pemeliharaan hasil-hasil pembangunan tetapi pelaksanaan pembangunan ini.Tapi pelibatan kaum wanita secara langsung masih pada akhir-akhir kurang perhatian perlu ditingkatkan. (3) Peranan Pemerintah lagi.Peralatan yang sudah rusak tidak Desa dalam mengawasi dan mengendalikan segera diganti oleh pengelola.Jadi kami pelaksanaan PPIP di Desa Sendana, dapat hanya memanfaatkan peratan yang dikatakan tergolong cukup baik. Pemerintah masih bisa di pakai, bahkan kami Desa Sendana melakukan pendekatan kepada 
pengelola untuk memperhatikan prinsip- langsung kepada masyarakat, pelatihan juga prinsip PPIP dan penggunaan anggaran perlu diadakan bagi Aparat Desa guna sesuai dengan peruntukkannya. (4) Peranan meningkatkan SDM dan memberikan Pemerintah Desa dalam Membina Organisasi pelayanan yang optimal bagi warga Masyarakat Desa Sendana sebagai masyarakat Desa Sendana.

penanggung jawab pelaksanaan PPIP dapat dikatakan tergolong baik. Hal ini dibuktikan dengan pembinaan organisasi masyarakat dilakukan oleh Pemerintah desa melalui DAFTAR PUSTAKA

nilai-nilai kearifan lokal dan modal sosial agar sikap dan perilaku organisasi masyarakat menjadi lebih baik. Pembinaan ini diharapkan dapat menghasilkan pembangunan infrastruktur pedesaan yang maksimal dan berkualitas, sehingga manfaatnya bagi masyarakat dapat dirasakan untuk waktu yang cukup lama. (5) Faktor yang mendukung peranan Pemerintah Desa dalam pelaksanaan PPIP di Desa Sendana, diantaranya dukungan dari masyarakat berupa keinginan untuk ikut terlibat melaksanakan pembangunan infrastruktur; dana operasional yang tersedia membantu proses pelaksanaan PPIP; dan Fasilitator Masyarakat (FM) membantu pemerintah desa dalam memberikan motivasi, bimbingan dan pembinaan kepada masyarakat. (6) Faktor yang menghambat Peranan Pemerintah Desa dalam Pelaksanaan PPIP di Effendi, Bachtiar. 2002. Pembangunan Daerah Desa Sendana diantaranya tingkat pendidikan masyarakat yang relatif rendah dan sarana dan prasarana berupa peralatan kerja masyarakat tidak mendukung sampai Hikmat, Harry. 2010. Strategi Pemberdayaan pada akhir pelaksanaan fisik.

Peningkatan peranan Pemerintah Desa dalam Pelaksanaan Program Pembangunan Infrastruktur Pedesaan (PPIP) Muthar. Pelaksanaan Fungsi Manajemen harus lebih ditingkatkan terutama dalam hal partisipasi masyarakat dalam setiap tahapan pengelolaan PPIP, penjaminan terhadap keterlibatan orang miskin dan kaum perempuan dalam setiap tahapan kegiatan, penyediaan fasilitas dan pembinaan Nurcholis, Hanif. 2011. Pertumbuhan \& masyarakat yang tergabung dalam OMS. Hal Penyelenggaraan Pemerintahan Desa. ini perlu dilakukan karena pelaksanaan program PPIP di Desa Sendana masih terdapat berbagai persepsi dari masyarakat. Pamudji, S. 1985. Perbandingan Pemerintahan. Jakarta: Pemerintah Desa dalam pelaksanaan Program PPIP, selain pembinaan secara Masyarakat. Bandung: Humaniora Utama Press (HUP).

Dalam Peningkatan Kinerja Pegawai Negeri Sipil Di Kantor Bupati Mamasa. Polman: Universitas Al-Asyaria'ah Mandar

Jakarta: Erlangga. 
Patton, Adri. 2005. Pemimpin Informasi, Budaya Lokal dan Pembangunan Daerah. Malang: Agritek Yayasan Pembangunan Nasional Malang.

Siagian, Sondang P. 2000. Manajemen Sumber Daya Manusia. Jakarta: Bumi Aksara.

Sumpeno, Wahyudin. 2009. Menjadi Fasilitator Genius. Yogyakarta: Pustaka Pelajar.

Soetopo, H dan Soemanto, W. 1991.Pengantar Operasional Administrasi Pendidikan. Surabaya: Usaha Nasional

Wasistiono, Sadu dan Irwan Tahir. 2007. Prospek Pengembangan Desa. Bandung: Fokusmedia

Widjaja. 2003. Otonomi Desa. Jakarta: PT. Raja Grafindo

Winardi, 2000, Manajer dan Manajemen. Bandung: Citra Aditya Bakti.

Verawati, Tuti A. 2003. Peran Pemerintah Dalam Pemberdayaan Masyarakat Nelayan di Kecamatan Tempe Kabupaten Wajo. Makassar: Universitas 45 Makassar

Dokumen :

Undang-Undang Pemerintahan Daerah 32 Tahun 2004

Undang-Undang No. 26 Tahun 2006 Tentang Pembentukan Provinsi Sulawesi Barat. 